\title{
How to Achieve Marketization of Rural Land Transfer
}

\author{
Hui Zhang ${ }^{1}$, Feng Gao $^{2}$ \\ ${ }^{1}$ Department of Economics and Management, Jining University, Qufu, 273155, China \\ ${ }^{2}$ Jining Municipal Bureau of land and resources, Jining, 272001, China
}

Keywords: Rural land transfer, Marketization, Institutional innovation

\begin{abstract}
Unification of urban and rural development becomes key word of government and other relevant departments. Implementation of such work mainly depends on flow of rural land production among each kinds of commerce. But, current rural land transfer work has some problems, such as no perfect transfer market and risks in land indexes. These problems give rise to serious impacts on rural land transfer. Thus, relevant departments should enhance management of rural land transfer, adopt effective measures, solve problems and lay a good foundation for rural development.
\end{abstract}

\section{Introduction}

With development of national economy, vulnerable rural group in China is valued, and agriculture is also faced with severe challenges. At present, China and foreign countries compete fiercely in agriculture. Domestic agriculture development is slow, and Chinese land has such problems as low use efficiency and insufficient rural productivity. Thus, the state must boost land transfer marketization, standardize land transfer behaviors, establish social security in rural areas, perfect it, strictly limit the quantity of land used for public benefit activities, establish and perfect relevant systems of land use right and promote land compensation diversification. Only when the state and relevant departments continuously analyze land transfer problems, and gain effective solutions can rural economy can improve. Meanwhile, national development can be ensured.

\section{Factors restricting rural land transfer marketization}

\section{Property right of rural land}

No explicit subject of property right

Relevant constitution stimulates except state-owned land, collectively-owned land includes home site and private plot, but it has no explicit ownership. Rural collective land is managed by cooperative or village committee. Collective land owned by peasants is managed by relevant rural collective economic organization. Superficially, these provisions specify ownership of rural land, while laws fail to specify the subject of property right. Some rural cooperative organizations appropriate the property right. This may easily lead to property right disputes. Some land property rights become obscure due to the influence of group of villagers, which will often become the excuse of benefit contending. According to relevant investigations, when the land in a village is transferred to scale production, peasants propose production benefit should be allocated to individuals by production group. The village branch proposes that production benefit should be allocated to individuals by village collective. Such dispute may easily make transfer item shelved and result in negative effects on rural development.

No complete land property right

Rural land has no complete land property right, which is mainly reflected in the following. Firstly, peasant collective lacks complete land disposal right. When peasant collective is land owner and has no complete disposal right, land disposal right is still controlled by the government, and peasants even have no the opportunity to publish ideas. Whether peasants own land property right is reflected by land disposal right. But, relevant laws provide that disposal right of rural collective land finally belongs to the government. When the state expropriates land, either party shall not resist. When the government and peasants have disputes in land property right, the government occupies certain 
advantage in laws. Legal status of peasants and government cannot be equal. So, in terms of land acquisition and price, peasants have no right to make decisions. This greatly affects rural development. Secondly, there is no stable contracting operation right. At present, some peasant households have no explicit operation right in the process of contracting land. The state frequently adjusts land-related systems so that peasants not just lack security sense of use right, and cannot invest in land. In recent years, urbanization course speeds up, and most peasants choose to work in cities. Thus, the phenomenon of rural land waste is serious. Meanwhile, local government may cancel contracting contract anytime in land contracting process so that peasants' legal rights and interests are violated. Since ancient times, land is the foundation of most peasants. When peasants' land use right is deprived, poverty phenomenon may occur easily. Thus, in terms of land property right system, peasants' benefits are not protected, and even damaged. This hinders development of rural economy.

\section{No formulation of land transfer intermediary system}

In land transfer process, transaction process is complex. To make land transaction smooth, there should be professional intermediary organizations, mainly including land appraisal and measurement organization, organization offering land transfer information, organization offering land transfer funds, and organization offering legal knowledge. But, some Chinese rural areas fail to set up relevant organizations, and land transfer intermediary agencies are few. Even if intermediary agencies are set up in some areas, no intermediary system is formulated. Land transfer market is not standard, and land transfer information cannot be updated in time. Thus, when peasant households transfer land, few can find out suitable transferors. This seriously affects land transfer and optimization. The influence of intermediary problem of rural land transfer on rural areas is mainly reflected in the following. Firstly, there is short of intermediary organization for land transfer. Some rural areas have no intermediary organization for land transfer. Thus, land transaction is hindered. The number of land transactions is small and reliability is low. In recent years, rural productivity increases gradually. If rural areas have not established intermediary organization for land transfer, rural intermediary organization for will be affected certainly. This restricts rural development. Secondly, peasants lack legal consciousness. Peasants in some areas have no legal consciousness. Thus, land transaction cannot be conducted as per laws and regulations. Professional contracts are seldom signed, and there is even no written text. Both the buyer and the seller reach an agreement in verbal form. It is very hard to guarantee peasants' rights and interests. Some peasants do not know they own land transfer right and inheritance right, and have no awareness of signing contracts. This is also the major cause why peasants' rights are infringed. Thirdly, land transfer cost is high. In land transaction process, land transaction can be bargained. In this way, cost will rise. For example, the buyer should know traders' contract information and transaction conditions before land transfer. These need much expenditure. This will increase the cost. In rural land transfer process, unnecessary expenses will be incurred without intermediary organization. Land buyer will expend excessive transaction expenses. This will restrict land transfer. These problems will influence rural development and bring hidden danger for peasants' economic effect.

\section{Lack of thorough land expropriation system}

The government formulates land expropriation system for the benefit of the public. The government compulsively gains peasants' land and gives some compensation as per laws. In order to improve people's living standards, the state uses the land expropriated for infrastructure construction concerning international people's livelihood, which can facilitate national economic development. But, some problems occur in national land expropriation system, such as lack of standard expropriation behavior and lack of equal compensation behavior. This is mainly because land expropriation system has defects. This is also the case for problems in land expropriation process. Although land expropriation system has experienced several adjustments, defects still exist. Firstly, peasants have no land disposal right. Although laws explicitly stipulate village-level land property right should be owned by peasants, rural land property right is grasped by township government in actual life. The state and the government utilize administrative force to deprive peasants' land economic income right. Relevant laws provide that construction in any aspect must use national public land. National land belongs to peasant collective. However, use right of these lands are grasped 
by the government. So, some peasants lose land use right and decision-making right. In terms of land expropriation, they have no the right to decide the price so that peasants' rights and interests are damaged. Secondly, there is short of the concept of public interest. Land acquisition means the state occupies peasants' land for public interest rather than making profit. To avoid abuse of land acquisition right by the government, the state formulates relevant land constitutions which explicitly indicate "the land expropriated by the state must be for the purpose of public interest". But, the laws do not specify the range of public interest. Unclear contents make some governments occupy state-owned land in the name of land expropriation after governments establish cooperative relationship with enterprises. However, most of these enterprises are state-owned enterprises. Since laws do not stipulate the range of public interest, state-owned enterprises operate for public interest in some sense. Thus, social fairness declines and even land expropriation behavior is transformed to land speculation problem. Thirdly, there is short of rational compensation behavior. At present, national economic conditions are limited and cannot give peasants whose lands are expropriated corresponding compensation. After peasants' lands are expropriated, their fundamental life cannot be guaranteed. After some enterprises expropriate lands, they do not resettle the peasants who lose their lands, and the government does not allocate work for peasants. Besides, the state fails to formulate reasonable compensation system. Finally, peasants are infringed. Therefore, rural economic development is restricted.

\section{Measures to achieve rural land transfer marketization}

\section{Normatively handle relationship between government and market}

In rural land transfer process, the state should curb the government from utilizing administrative means to damage peasants' interests, and drive land transfer in the market with the approval of peasants. Any government shall neither force to take back land contracted by peasants nor improve transaction cost of peasants' land at random. Governments should indirectly motivate peasants' enthusiasm in land transfer and confirm peasants' subjectivity. The state should require the government no longer intervene in land transfer matters and serve for peasants so as to make government's functions transform to service from administration and promote development of land transfer market rules. Hence, the state should handle well the relationship between the government and market to give full play to maximum functions of the two. This not merely promotes rural land transfer, but also exerts land allocation function so as to improve land use efficiency and achieve development of both peasants and enterprises in normative market ${ }^{[1]}$.

\section{Enhance construction of rural land transfer marketization}

At present, the most important work of the state in rural reform is to enhance rural land transfer marketization. Hence, the state should establish compensation system for land transfer and investment and take effective measures to boost land transfer market development on the basis of modern rural construction. Relevant laws and regulations should not just be perfected, but also be effectively applied in rural land transfer process. Measurements for rural land market standardization mainly include the following:

\section{Legislation for land transfer marketization}

To stabilize rural land rural land, laws should be utilized to protect peasants' rights and interests, standardize contracting right and make transfer market sound development. The state should formulate land contracting and relevant systems, legislate for land use right transfer, subdivide the responsibilities and rights of land transfer supervision department and standardize land transfer form and procedure. The state should define peasants' rights in land transfer process, explicitly specify peasants' income distribution in the legislation and the ways to handle disputes, carefully study land transfer market, formulate normative laws and regulations, and guide transfer market to get on the right track ${ }^{[2]}$.

\section{Standardize marketization management}

Land transfer involves a large range, including land owner, operation enterprise and intermediary agency etc. In the transfer process, operation procedures must be standard. Firstly, after land transfer matters are confirmed, legal transfer contract should be signed. The contract must be made in written 
form. Secondly, transfer conditions should be specified in the contract, including transfer form, land area, land age and all kinds of expenses etc. Land owners must stipulate land purpose and clearly indicate responsible aspects after the transfer. Finally, transfer contract can take effect after relevant department notarizes it $^{[3]}$. The government should register transferred land to prevent unnecessary problems and damages to peasants' interests.

Train transfer intermediary organizations and peasants

Since some rural areas lack thorough land transfer intermediary market so that peasants have to employ personnel from the agency and price evaluation units in land transfer process, which results to the rise in transfer cost. Thus, the state should carry out professional knowledge training for workers in land transfer market, educate them in batches regularly, arrange professional personnel to supervise land transfer work, guide handling of land transfer formalities and adjust relations of various aspects so as to make land transfer working procedure more standard ${ }^{[4]}$.

Land transfer organization should be trained. Meanwhile, relevant knowledge should be conveyed to peasants. The state should improve peasants' educational level and liberate them from traditional constraints. On this basis, peasants' labor skills should be enhanced. In this way, peasants' thought can be opened, and peasants' employment rate can improve. This contributes to alleviating peasants' dependence on land and laying a favorable foundation for development of land transfer market ${ }^{[5]}$.

The state should guide agriculture to develop towards modernization, encourage peasants to introduce modern agricultural technology and equipment, arrange professional personnel to guide in rural areas, make peasants master advanced agricultural knowledge and operate agricultural equipment, promote the rise in agricultural production value, increase peasants' economic income and offer beneficial help for national development.

\section{Conclusions}

In conclusion, to standardize rural land transfer market, it is required to specify land property right and perfect relevant laws and regulations. The state should carefully study problems in rural land transfer, adopt effective measures to solve them, educate peasants, make then maintain their benefits by laws, organize land transfer personnel to train then regularly, promote specialization of land transfer market and maintain peasants’ interests.

\section{Acknowledgments}

This paper is the topic of Shandong Federation of Humanities and Social Sciences, Which name is Study on Relationship between Government and Market in Shandong Land Contracting Operation Right Transfer (No.: No. 15-ZZ-JJ-24).

\section{References}

[1] Wang Shuai, Study on rural land transfer and labor force transfer in Ning'an City. Northeast Agricultural University, 2012.

[2] Sun Yuan, Study on linkage between rural land utilization and village tourism in Yunnan. Yunnan University of Finance and Economics, 2012.

[3] Shen Yun, Study on pricing mechanism of rural land use right. Jiangxi Agricultural University, 2012.

[4] Dong Bangying, Changes of peasants' operation objects based on perspective of scale operation. Anhui University, 2014.

[5] Song Hui, Study on behaviors of peasants, village committee and government in rural land transfer - expirical study based on peasants in Xiangyang City. Huazhong Agricultural University, 2013. 